\title{
Numerical Study of Fluid Flow over Bundle Tubes
}

\author{
Majid Almas ${ }^{1,2}$ \\ ${ }^{1}$ Department of Mechanical and Materials Engineering, Florida International University, Miami, FL, USA \\ ${ }^{2}$ Department of Marine Engineering, King AbdulAziz University, Jeddah, Kingdom of Saudi Arabia \\ Email: malma016@fiu.edu
}

How to cite this paper: Almas, M. (2016) Numerical Study of Fluid Flow over Bundle Tubes. Journal of Electronics Cooling and Thermal Control, 6, 109-119. http://dx.doi.org/10.4236/jectc.2016.63010

Received: June 6, 2016

Accepted: September 5, 2016

Published: September 8, 2016

Copyright $\odot 2016$ by author and Scientific Research Publishing Inc. This work is licensed under the Creative Commons Attribution International License (CC BY 4.0).

http://creativecommons.org/licenses/by/4.0/

\begin{abstract}
In this paper, a bank of tubes containing a flowing fluid which is immersed in a cross flow second medium of fluid with different temperature has been studied numerically using computational fluid dynamics. Laminar steady flow with a low Reynolds number has been studied in this work. Inlet mass flow rate and the bulk temperature are known and numerical method has been implemented to study the convective heat transfer to investigate the temperature and flow fields. Effects of different inlet bulk temperatures and mass flow rates have been investigated on temperature and pressure variations.
\end{abstract}

\section{Keywords}

Heat Transfer, Bundle Tube, Mass Flow Rate, Numerical Solution

\section{Introduction}

Periodic heat flows have broad industrial and engineering applications in steam generation in a boiler, condenser or air cooling in the coil of an air conditioner. Forced convection was broadly employed in different kinds of heat exchanger, and in many other applications in which the convective heat transfer has been studied and discussed. Theoretically calculation of heat transfer in a fully developed laminar flow in smooth pipe with uniform heat flux at the wall showed that the Nusselt number was constant [1]. A correlation for heat transfer forced convection has been proposed by Colburn [2] in which the comparison has been performed with fluid friction. The heat transfer of liquids in tubes has been studied experimentally by Sieder and Tate [3]. They derived the heat transfer correlation with viscosity ratio caused by heat transfer temperature difference. For the optimal design and operation of dry cooling systems to make clear the heat and mass transfer characteristics of air-cooled heat exchangers the demand on the performance of heat exchangers and the need to enhance their performance have 
been increased and this matter has been discussed by Gough [4]. In power plants where there is a shortage of water finned bundle tubes are frequently used to the air-cooled heat exchangers of the dry cooling system. The total thermal resistance for these kinds of heat exchangers includes three parts: the air-side convective thermal resistance, the wall conductive thermal resistance and the liquid-side convective thermal resistance. A lot of numerical and experimental studies have been done for improving the heat transfer performance of compact heat exchangers using slotted fins [5] and [6]. Ribatski and Jacobi [7] published a review of studies on tube bundle. In this study, a bank of tubes containing a flowing fluid at one temperature that is immersed in a second fluid in cross flow at a different temperature has been studied numerically. Effects of different inlet bulk temperatures and mass flow rate have been investigated on temperature and pressure variation.

\section{Problem Definition}

Figure 1 shows the schematic of the 2 dimensional section of a tube bank which has been studied in this paper. The bank of tubes with a diameter of $1 \mathrm{~cm}$ is staggered across the cross-fluid flow. They are arranged with uniform space. In the $\mathrm{x}$ and $y$-directions their centers are separated by a distance of 2 and $1 \mathrm{~cm}$ respectively. The depth of the tube bank is $1 \mathrm{~m}$. Because of symmetry of tube bank geometry, only a portion of the domain has been considered for simulation. The computational domain and the grid generation are shown in Figure 1 . The inlet mass rate is $0.05 \mathrm{~kg} / \mathrm{s}$ at the inlet
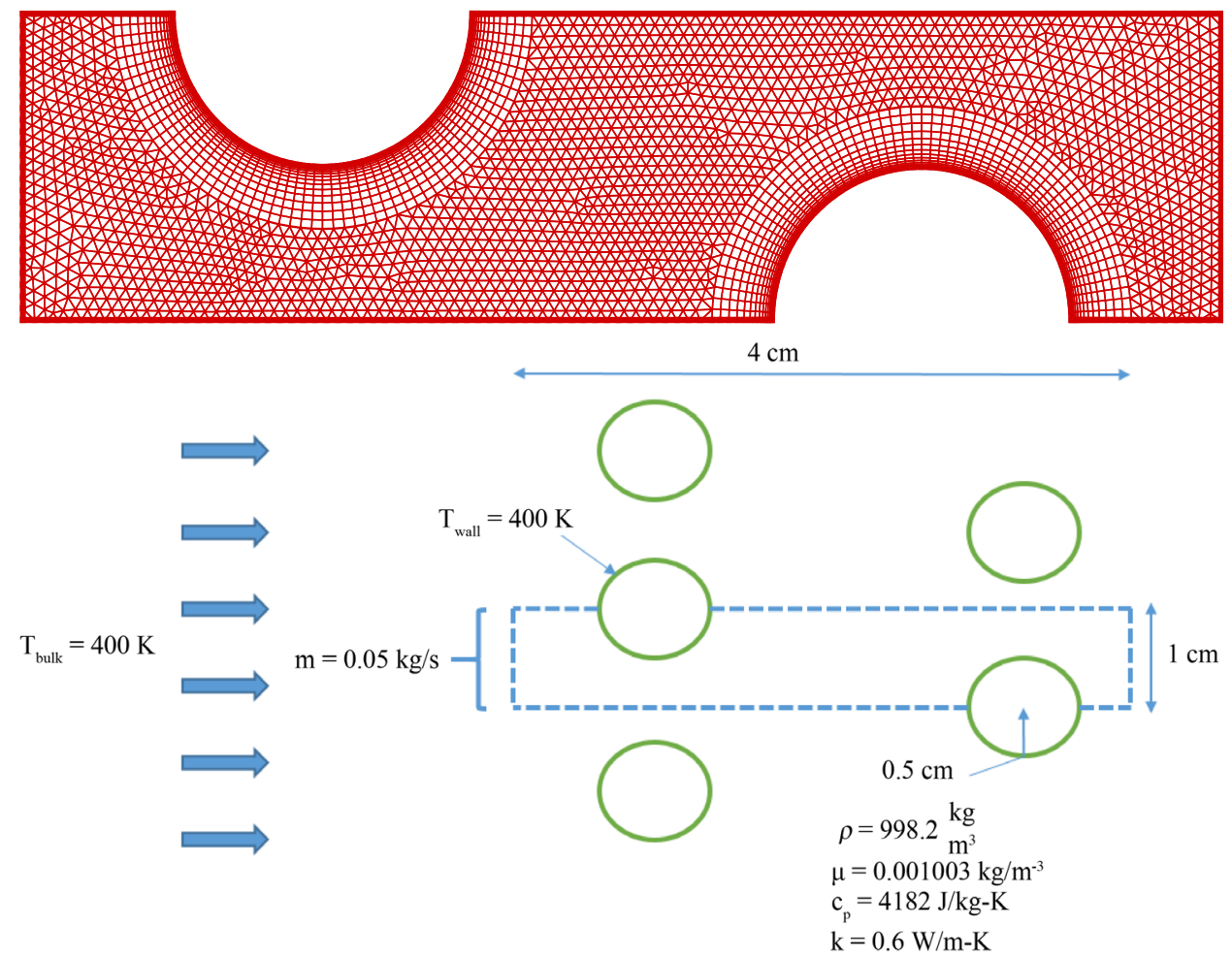

Figure 1. Geometry and grid generation of the problem. 
boundary of the periodic module. The temperature of the tube wall $\left(\mathrm{T}_{\text {wall }}\right)$ is $400 \mathrm{~K}$ and the bulk temperature of the cross flow water $\left(\mathrm{T}_{\text {bulk }}\right)$ is $300 \mathrm{~K}$. The physical water properties are also mentioned in Figure 1. A hybrid mesh has been used for the simulation. For the regions surrounding tube walls Quadrilateral cells and for the rest of the domain triangular cells have been used. Second order upwind has been used for both momentum and energy equations. The convergence criteria for continuity, momentum and energy are $10 \mathrm{e}-3,10 \mathrm{e}-3$ and $10 \mathrm{e}-6$ respectively.

\section{Results and Discussions}

Figure 2 shows the contours of pressure inlet bulk temperature of $300 \mathrm{~K}$ and mass flow rate of $0.05 \mathrm{~kg} / \mathrm{s}$. As shown in the figure, pressure has its maximum value where the inlet mass flow hit the front face of each tube and this value reduces as the flow moves downstream of the tube. The maximum value at the front side is $0.08 \mathrm{~Pa}$ and this value is at its lowest at the top and bottom of the tubes as seen in the paper and is around $0.006 \mathrm{~Pa}$ behind each tube.

Figure 3 depicts the contours of temperature at the inlet bulk temperature of $300 \mathrm{~K}$
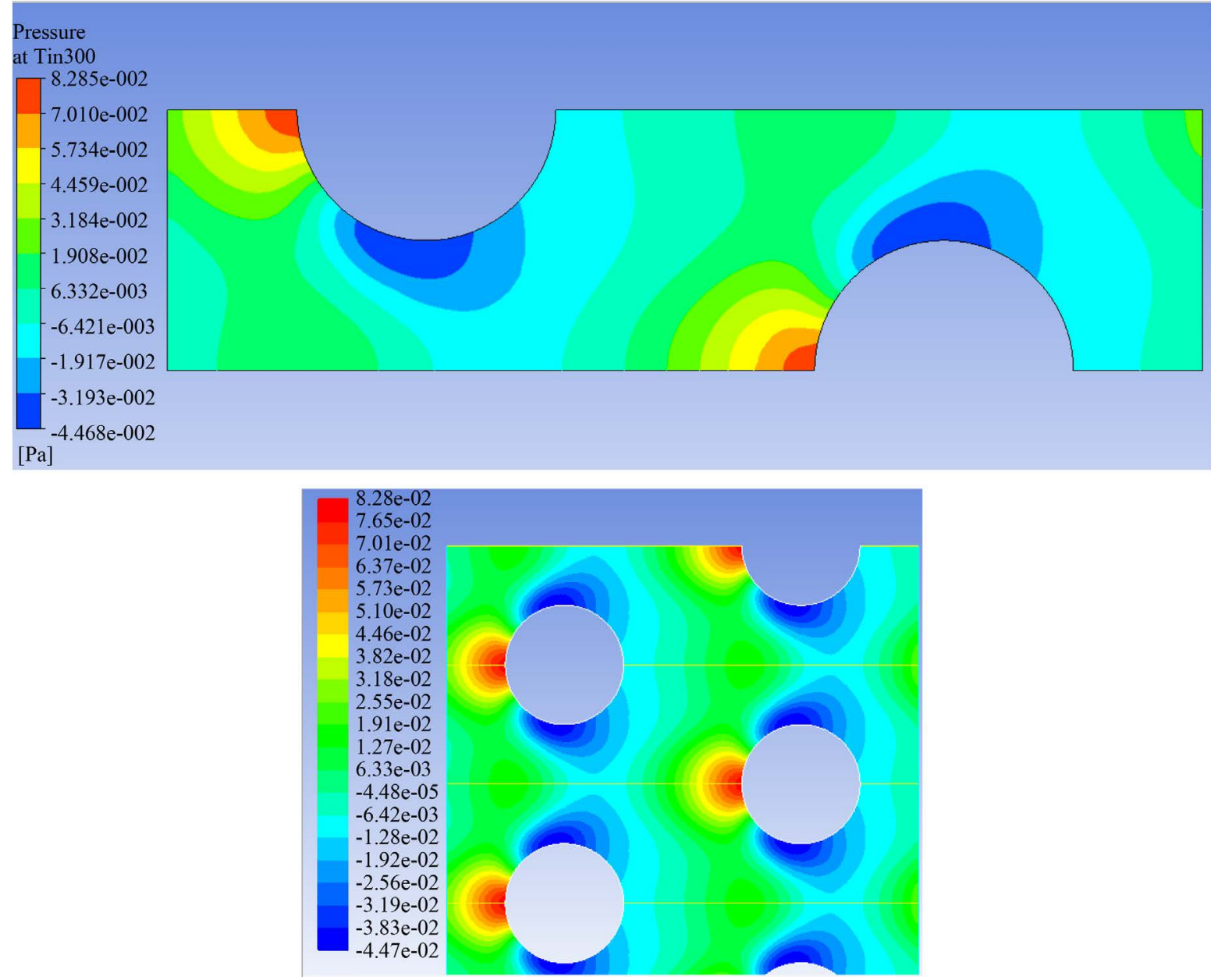

Figure 2. Pressure contour for inlet bulk temperature of $300 \mathrm{~K}$ and mass flow rate of $0.05 \mathrm{~kg} / \mathrm{s}$. 

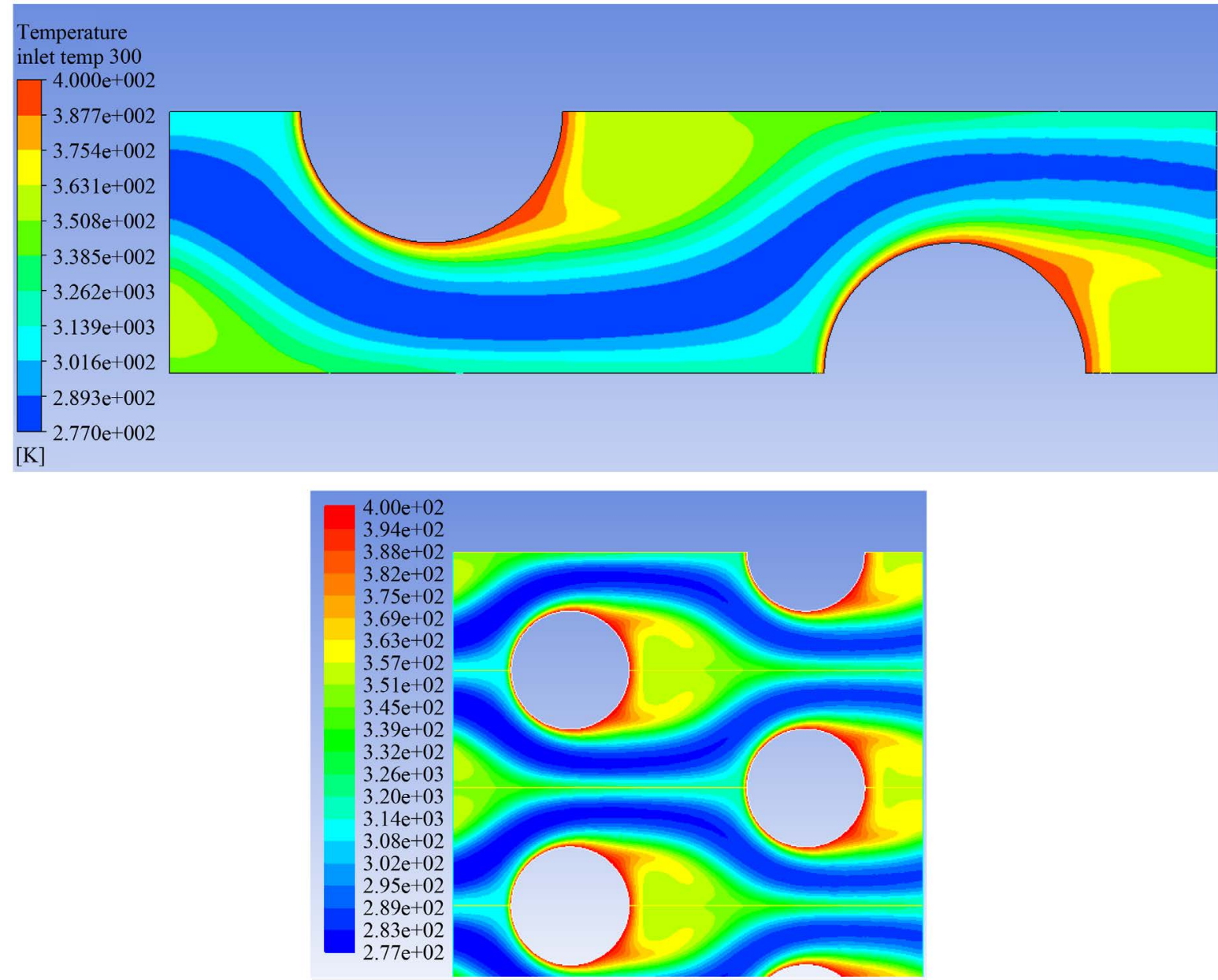

Figure 3. Temperature contour for inlet bulk temperature of $300 \mathrm{~K}$ and mass flow rate of $0.05 \mathrm{~kg} / \mathrm{s}$.

and mass flow rate of $0.05 \mathrm{~kg} / \mathrm{s}$. As shown in the figure, temperature has its maximum value as the initial surface temperature of each tube is $400 \mathrm{~K}$ which more than the inlet bulk temperature, $300 \mathrm{~K}$. As the inlet flow passes over the tube the temperature of the front tubes side decreases to around $360 \mathrm{~K}$. There is a pass between the tubes which has its lowest temperature value around $270 \mathrm{~K}$. As can be seen the value of temperature behind the tubes reduces to $360 \mathrm{~K}$.

Figure 4 displays the contours of temperature at the inlet bulk temperature of $500 \mathrm{~K}$ and mass flow rate of $0.05 \mathrm{~kg} / \mathrm{s}$. As shown in the figure, the initial surface temperature of each tube is $400 \mathrm{~K}$ which less than the inlet bulk temperature, $470 \mathrm{~K}$. As the inlet flow passes over the tube the temperature of the front tubes side increases to around $360 \mathrm{~K}$. There is a pass between the tubes which has its highest temperature value around $520 \mathrm{~K}$. As can be seen the value of temperature behind the tubes increases to $450 \mathrm{~K}$.

Figure 5 displays the contours of temperature at the inlet bulk temperature of $700 \mathrm{~K}$ and mass flow rate of $0.05 \mathrm{~kg} / \mathrm{s}$. In this figure the inlet bulk temperature increases even more to 700 to see how the flow field temperature increases over the tube bundles. As 

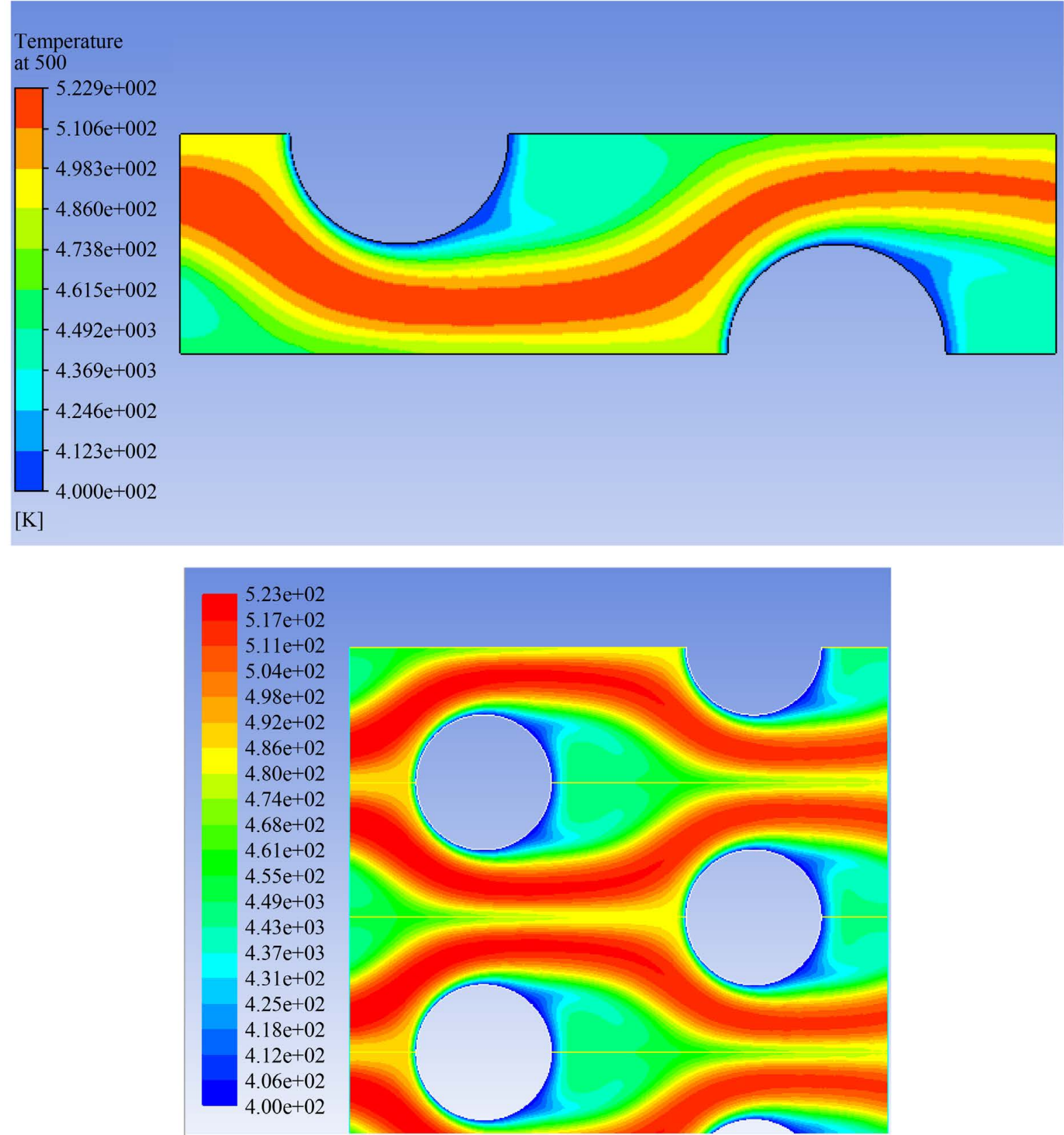

Figure 4. Temperature contour for inlet bulk temperature of $500 \mathrm{~K}$ and mass flow rate of $0.05 \mathrm{~kg} / \mathrm{s}$.

shown in the figure, the initial surface temperature of each tube is $400 \mathrm{~K}$ which less than the inlet bulk temperature, $700 \mathrm{~K}$. As the inlet flow passes over the tube the temperature of the front tubes side increases to around $620 \mathrm{~K}$. There is a pass between the tubes which has its highest temperature value around $760 \mathrm{~K}$. As can be seen the value of temperature behind the tubes increases to $550 \mathrm{~K}$.

Figure 6 demonstrates the temperature profiles at three different locations of 0.01 , 0.02 and $0.03 \mathrm{~m}$ for the inlet bulk temperature of $300 \mathrm{~K}$ and mass flow rate of $0.05 \mathrm{~kg} / \mathrm{s}$. As seen in the figure at location $\mathrm{x}=0.01 \mathrm{~m}$ the temperature value drops from $330 \mathrm{~K}$ to 

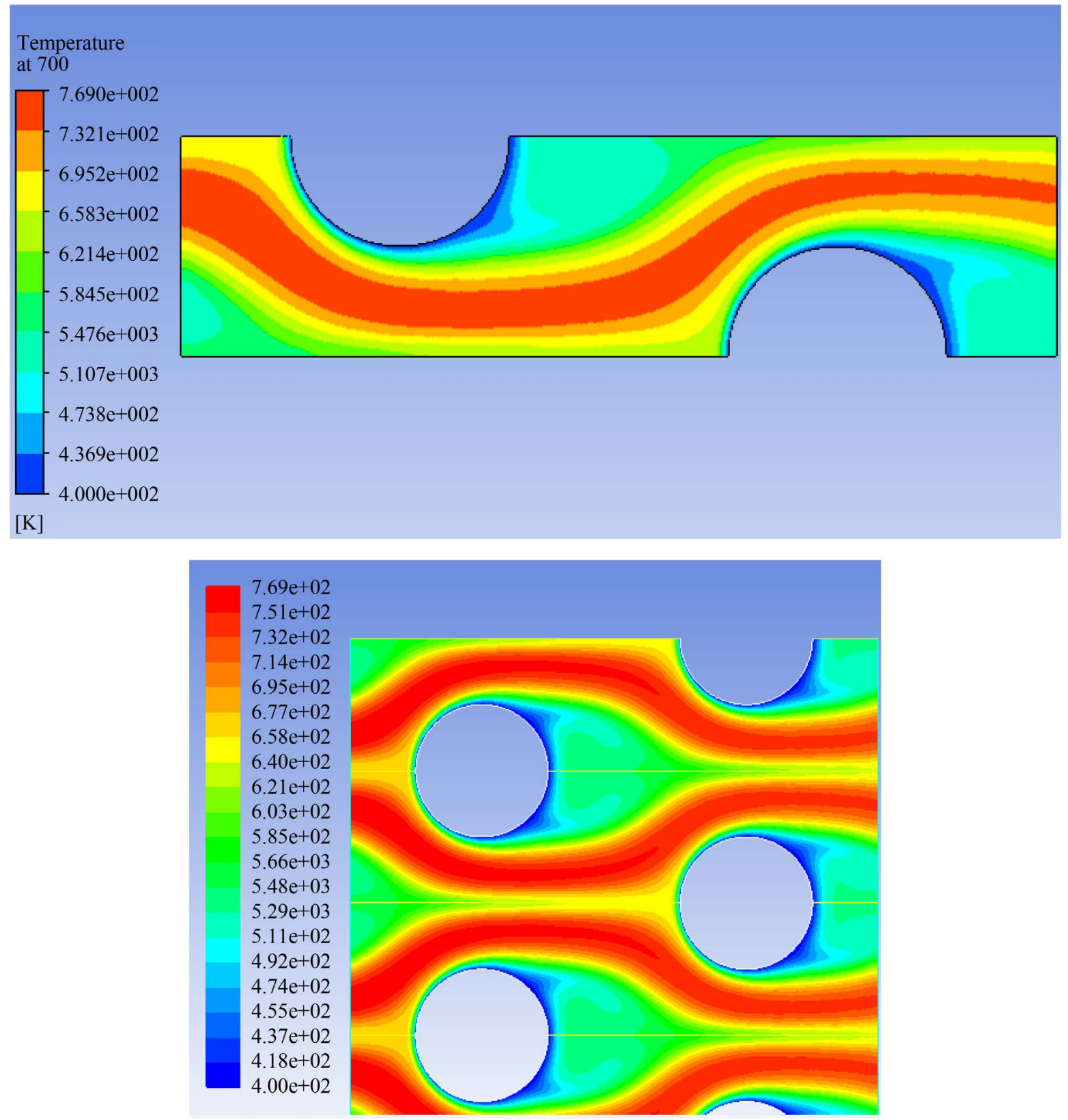

Figure 5. Temperature contour for inlet bulk temperature of $700 \mathrm{~K}$ and mass flow rate of $0.05 \mathrm{~kg} / \mathrm{s}$.

$280 \mathrm{~K}$ and thereafter in increases sharply to the surface temperature of the tube, $400 \mathrm{~K}$. At location $\mathrm{x}=0.02 \mathrm{~m}$, the temperature decreases from $320 \mathrm{~K}$ to around 280 and then increases to about $360 \mathrm{~K}$ and slightly reduces to $350 \mathrm{~K}$. At location $\mathrm{x}=0.03 \mathrm{~m}$ the temperature dramatically drops from tube surface temperature of $400 \mathrm{~K}$ to around $280 \mathrm{~K}$ and then increases to $340 \mathrm{~K}$.

Figure 7 demonstrates the temperature profiles at three different locations of 0.01 , 0.02 and $0.03 \mathrm{~m}$ for the inlet bulk temperature of $500 \mathrm{~K}$ and mass flow rate of $0.05 \mathrm{~kg} / \mathrm{s}$. As seen in the figure at location $\mathrm{x}=0.01 \mathrm{~m}$ the temperature value increases from $470 \mathrm{~K}$ to $520 \mathrm{~K}$ and quickly drops sharply to the tube surface temperature of $400 \mathrm{~K}$. At location 


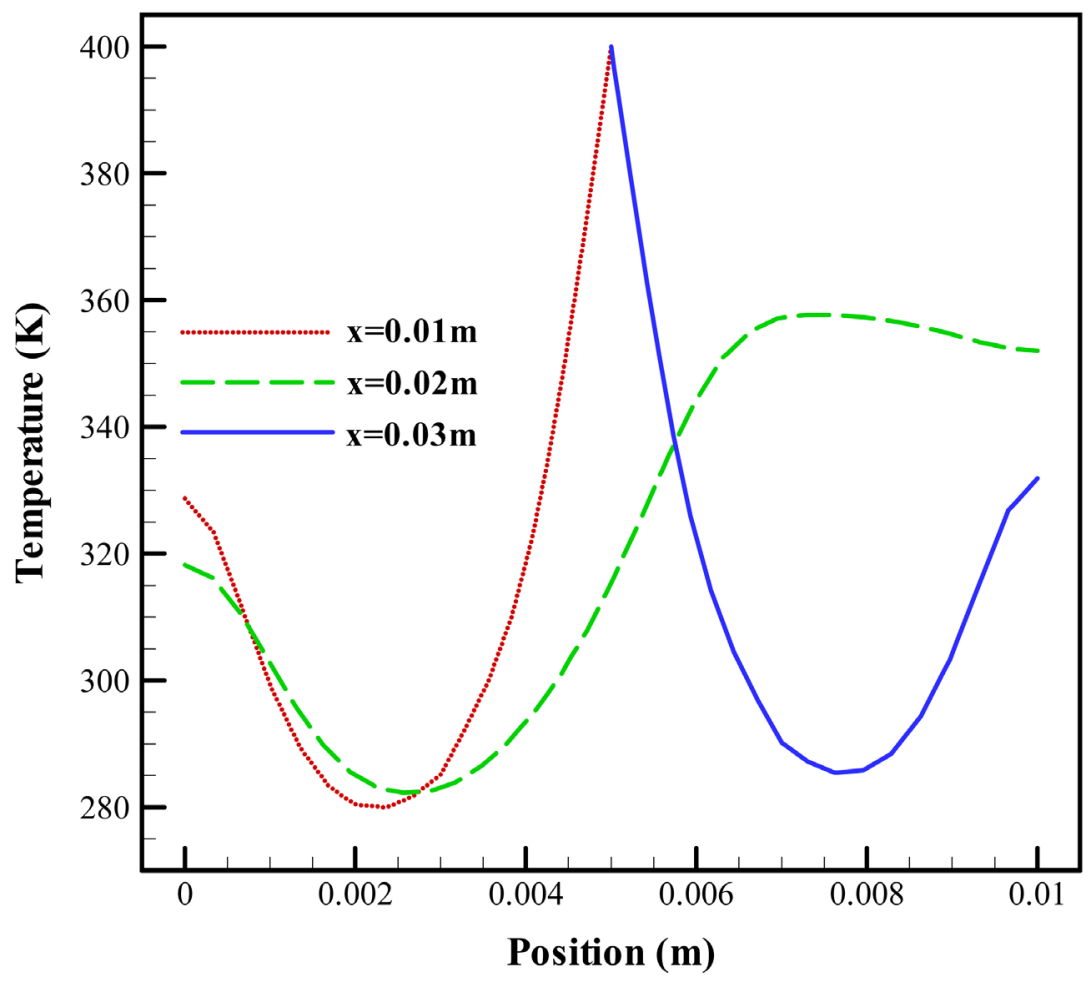

Figure 6. Temperature profiles for inlet bulk temperature of $300 \mathrm{~K}$ and mass flow rate of $0.05 \mathrm{~kg} / \mathrm{s}$ at locations $0.01,0.02$ and $0.03 \mathrm{~m}$.

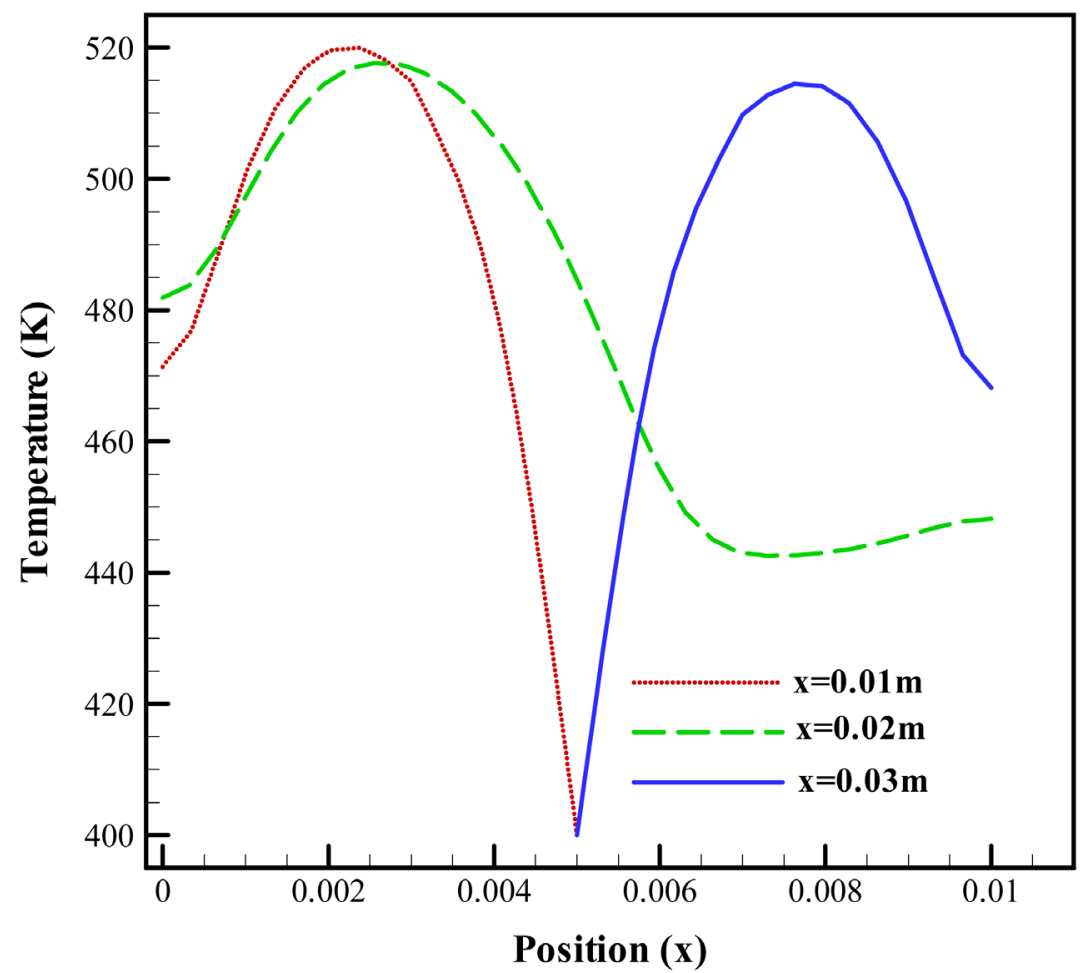

Figure 7. Temperature profiles for inlet bulk temperature of $500 \mathrm{~K}$ and mass flow rate of $0.05 \mathrm{~kg} / \mathrm{s}$ at locations $0.01,0.02$ and $0.03 \mathrm{~m}$. 
$\mathrm{x}=0.02 \mathrm{~m}$, the temperature increases from $480 \mathrm{~K}$ to almost 520 and then decreases to about $440 \mathrm{~K}$ and stays constant around this temperature. At location $\mathrm{x}=0.03 \mathrm{~m}$ the temperature dramatically grows from tube surface temperature of $400 \mathrm{~K}$ to around 510 $\mathrm{K}$ and then reduces to $460 \mathrm{~K}$.

Figure 8 shows the temperature profiles at three different locations of $0.01,0.02$ and $0.03 \mathrm{~m}$ for the inlet bulk temperature of $700 \mathrm{~K}$ and mass flow rate of $0.05 \mathrm{~kg} / \mathrm{s}$. As seen in the figure at location $\mathrm{x}=0.01 \mathrm{~m}$ the temperature value increases from $600 \mathrm{~K}$ to $760 \mathrm{~K}$ and quickly drops sharply to the tube surface temperature of $400 \mathrm{~K}$. At location $\mathrm{x}=0.02$ $\mathrm{m}$, the temperature increases from $640 \mathrm{~K}$ to almost 760 and then decreases to about 540 $\mathrm{K}$ and stays constant around this temperature. At location $\mathrm{x}=0.03 \mathrm{~m}$ the temperature dramatically grows from tube surface temperature of $400 \mathrm{~K}$ to around $750 \mathrm{~K}$ and then decreases to $600 \mathrm{~K}$.

Here in Figure 9 and Figure 10, the effects of inlet mass flow rates have been studied on flow field over the bundle tubes. Figure 9 shows the Pressure contour for inlet bulk temperature of $300 \mathrm{~K}$ and mass flow rates of $0.05,0.09$ and $0.13 \mathrm{~kg} / \mathrm{s}$. As can be seen through the figures the value of pressure increases as the inlet mass flow rate grows. At mass flow rate of $0.05 \mathrm{~kg} / \mathrm{s}$ the static pressure is $0.082 \mathrm{~Pa}$ and this value increases to 0.25 and 0.54 for in let mass flow rates of 0.09 and $0.13 \mathrm{~kg} / \mathrm{s}$ respectively. As also can be seen from the figures the pressure contours at the top and bottom of the tube become smoother with less sharps edges and also more evenly distributed.

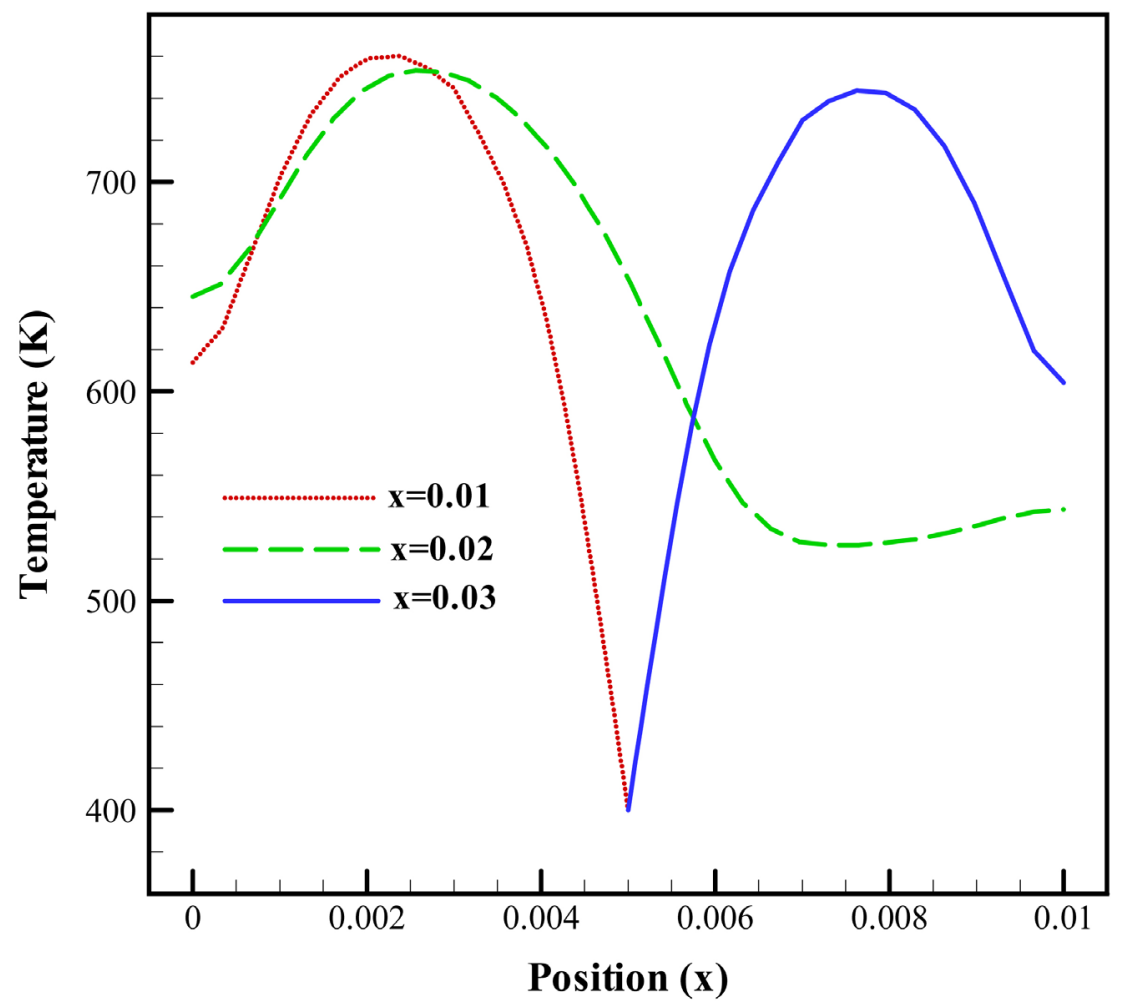

Figure 8. Temperature profiles for inlet bulk temperature of $700 \mathrm{~K}$ and mass flow rate of $0.05 \mathrm{~kg} / \mathrm{s}$ at locations $0.01,0.02$ and $0.03 \mathrm{~m}$. 

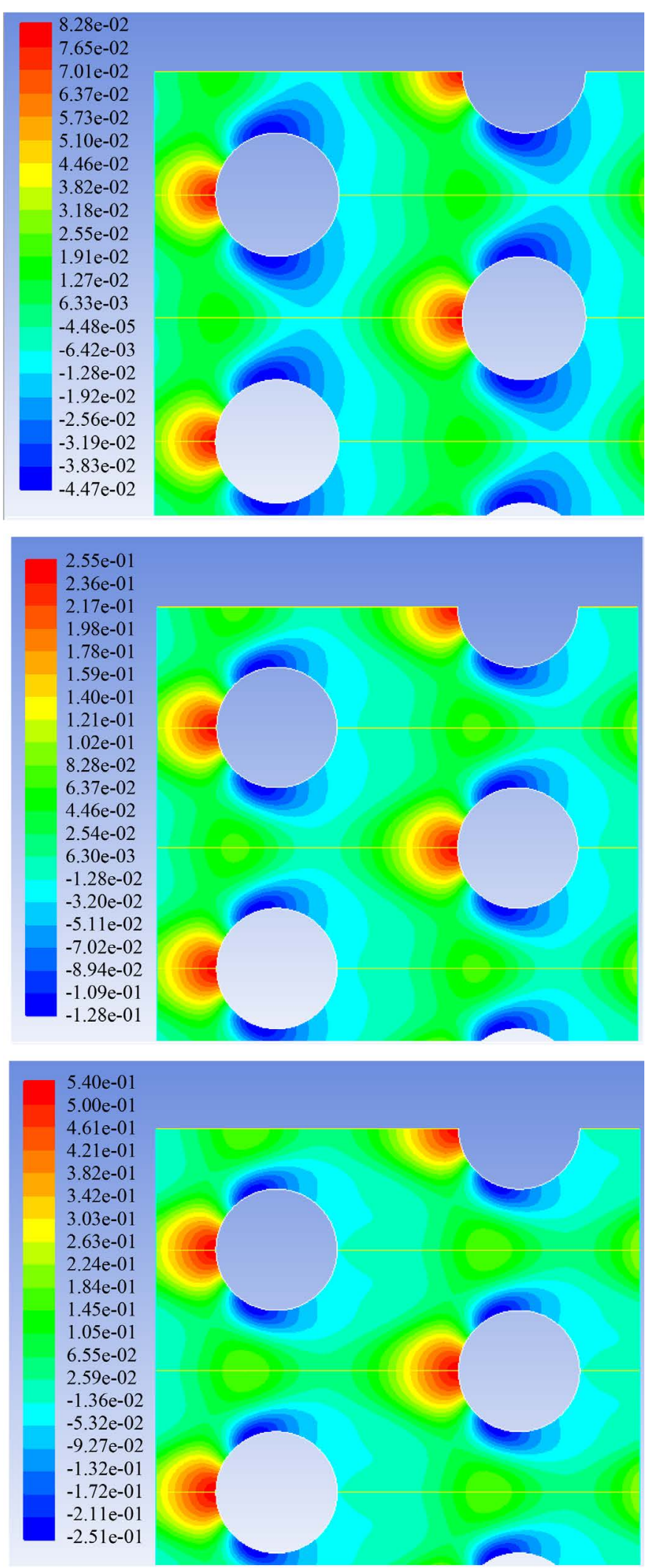

Figure 9. Pressure contour for inlet bulk temperature of $300 \mathrm{~K}$ and mass flow rate of $0.05 \mathrm{~kg} / \mathrm{s}$ at locations $0.05,0.09$ and $0.13 \mathrm{~m}$. 

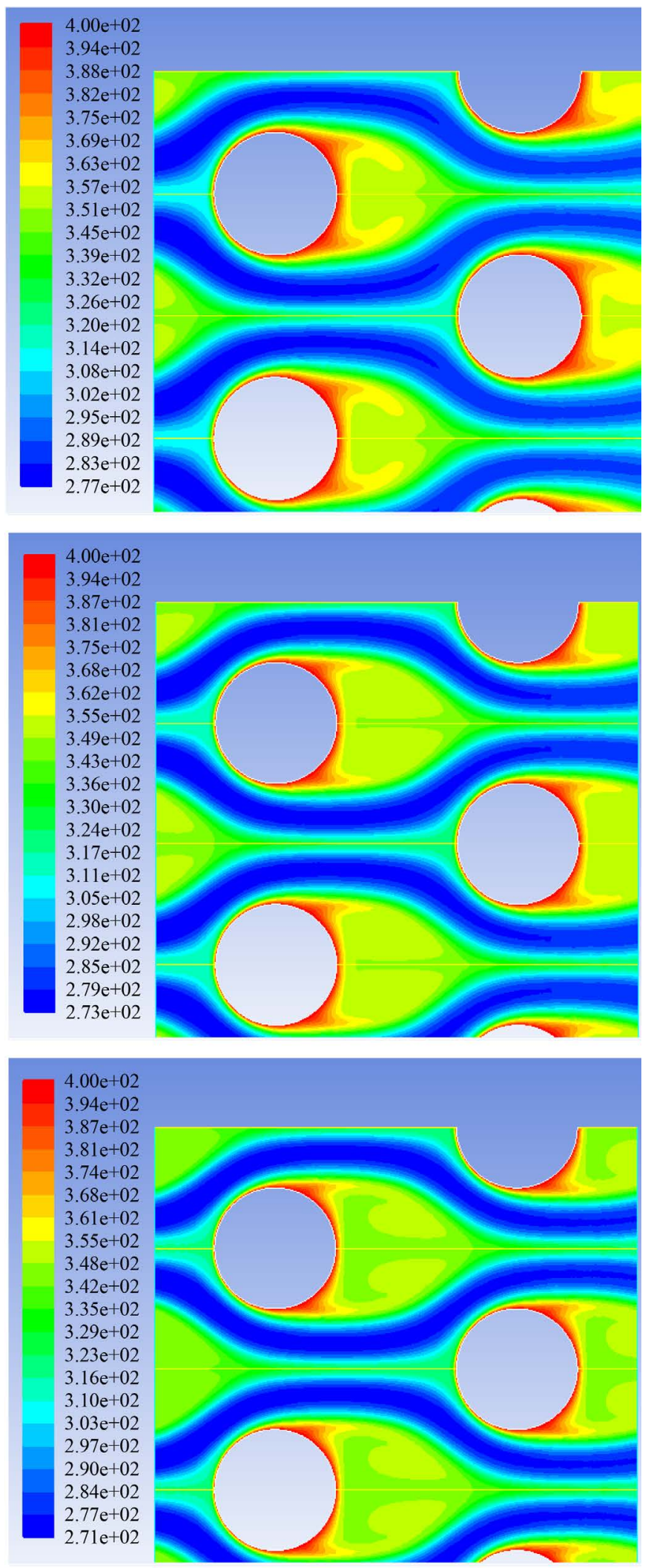

Figure 10. Temperature contour for inlet bulk temperature of 300 $\mathrm{K}$ and mass flow rate of $0.05 \mathrm{~kg} / \mathrm{s}$ at locations $0.05,0.09$ and $0.13 \mathrm{~m}$. 
Figure 10 depicts the temperature contour for inlet bulk temperature of $300 \mathrm{~K}$ and mass flow rates of $0.05,0.09$ and $0.13 \mathrm{~kg} / \mathrm{s}$. As can be seen through the figures the value of surface tube temperature does not change but the flow field around the tubes changes and becomes stronger. The temperature contours become sharper behind the tubes and the temperature boundary layer gets thinner as the inlet mass flow rates increases form $0.05,0.09$ to $0.13 \mathrm{~kg} / \mathrm{s}$.

\section{Conclusion}

Effects of different inlet bulk temperatures and mass flow rate have been investigated on temperature and pressure variation. As numerical results show, the value of pressure increases as the inlet mass flow rate grows and the temperature contours become sharper behind the tubes and the temperature boundary layer gets thinner as the inlet mass flow rates increase. The surface temperature reduces as the inlet bulk temperature passes over the bundle tubes with lower temperature and this value increases as the inlet flow temperature increases to the higher value than the surface temperature.

\section{Acknowledgements}

The author would like to thank both the Saudi Arabian Cultural Mission in Washington DC and King Abdulaziz University in Jeddah, KSA for their support.

\section{References}

[1] Shan, R.K. and Bhatti, M.S. (1987) Laminar Convective Heat Transfer in Ducts, Hand Book of Single-Phase Convective Heat Transfer. Wiley Interscience, New York

[2] Colburn, A.P. (1933) A Method of Correlating Forced Convection Heat Transfer Data and A Comparison with Fluid Friction. International Journal of Heat and Mass Transfer, 7, 1359-1384. http://dx.doi.org/10.1016/0017-9310(64)90125-5

[3] Sieder, E.N. and Tate, G.E. (1936) Heat Transfer and Pressure Drop of Liquids in Tubes. Industrial \& Engineering Chemistry Research, 28, 1429-1435. http://dx.doi.org/10.1021/ie50324a027

[4] Gough, M.J. (2011) Process Heat Transfer Enhancement to Upgrade Performance, Throughput and Reduced Energy Use. Chemical Engineering Transactions, 29, 1-6.

[5] Wang, Y., He, Y.L., Mei, D.H. and Tao, W.Q. (2011) Optimization Design of Slotted Fin by Numerical Simulation Coupled with Genetic Algorithm. Applied Energy, 88, 4441-4450. http://dx.doi.org/10.1016/j.apenergy.2011.05.030

[6] Yayla, S. (2013) Flow Characteristic of Staggered Multiple Slotted Tubes in the Passage of a Fin Tube Heat Exchanger. Strojniški Vestnik-Journal of Mechanical Engineering, 59, 462472. http://dx.doi.org/10.5545/sv-jme.2012.902

[7] Ribatski, G. and Jacobi, A.M. (2005) Falling Film Evaporation on Horizontal Tubes-A Critical Review. International Journal of Refrigeration, 28, 635-653.

http://dx.doi.org/10.1016/j.ijrefrig.2004.12.002 
Submit or recommend next manuscript to SCIRP and we will provide best service for you:

Accepting pre-submission inquiries through Email, Facebook, LinkedIn, Twitter, etc. A wide selection of journals (inclusive of 9 subjects, more than 200 journals)

Providing 24-hour high-quality service

User-friendly online submission system

Fair and swift peer-review system

Efficient typesetting and proofreading procedure

Display of the result of downloads and visits, as well as the number of cited articles

Maximum dissemination of your research work

Submit your manuscript at: http://papersubmission.scirp.org/ 